Teologia i Moralność, volumen 14(2019), numer 1(25)

doi: 10.14746/tim.2019.25.1.16

ORCID 0000-0003-4290-6743

HENRYK SŁAWIŃSKI

Papieski Uniwersytet Jana Pawła II w Krakowie

Wydział Teologiczny

\title{
Głoszenie uzdrowień w imię Jezusa i w mocy Ducha Świętego - przepowiadanie terapeutyczne
}

\section{Wprowadzenie}

Przepowiadanie terapeutyczne jest zagadnieniem, które było już podejmowane przez homiletów. Ryszard Hajduk (CSsR) napisał książkę zatytułowaną: Leczyć rany serc złamanych. Przyczynek do kaznodziejstwa terapeutycznego (Hajduk 1996). Omawia w niej uzdrawiającą posługę Jezusa, a także takie zagadnienia, jak: przemiany społeczne w Polsce i komunikację międzyludzką na płaszczyźnie relacji, treści oraz języka, a także terapeutyczne ukierunkowanie współczesnej teologii pastoralnej. W ramach tego ostatniego zagadnienia omówił mistagogię, towarzyszenie i gościnność. Kwestia terapeutyczna została więc osadzona w szerokim kontekście społecznym. Z kolei Marian Šuráb w książce Teraputický rozmer homílie (Šuráb 2008) wyróżnił pięć rozdziałów, w których omawia kolejno: terapeutyczną działalność Jezusa, sytuacje słuchaczy homilii, cechy homilii terapeutycznej i wreszcie posługę homilisty w procesie terapeutycznym. Piąty rozdział jest prezentacją przeprowadzonych badań nad słuchaczami.

W niniejszym opracowaniu chodzi o refleksję nad uzdrawiającym działaniem Ducha Świętego, które łączy się z posługą głoszenia słowa Bożego. Refleksja ta będzie zmierzać do wypracowania pewnych kryteriów pomocnych przy ewaluacji przepowiadania terapeutycznego. Ponieważ terapia oznacza poprawę zdrowia i samopoczucia człowieka przez stosowanie różnego rodzaju zabiegów, mówiąc o przepowiadaniu terapeutycznym, podkreślamy uzdrawiającą moc słowa Bożego i moc Ducha Świętego, która towarzyszy głoszeniu 
osoby i dzieła Jezusa Chrystusa, jedynego Zbawiciela człowieka. Innymi słowy jest to głoszenie Jezusa Chrystusa, który jest najlepszym lekarzem, uzdrowicielem człowieka.

Doświadczenie uzdrowienia jest szczególnie akcentowane na przykład we wspólnotach ruchu Odnowy w Duchu Świętym. Norbert Kokott w swej rozprawie doktorskiej pod tytułem Rola Ruchu Odnowy w Duchu Świętym w dynamizowaniu misji Kościoła wyczerpująco pisze o darze uzdrawiania (por. Kokott 2011, s. 167-182), a następnie nieco zwięźlej o sakramentach uzdrowienia: pokuty i pojednania oraz namaszczenia chorych (por. Kokott 2011, s. 182-189). Omawiając dar uzdrawiania, autor analizuje modlitwę o uzdrowienie podczas liturgii i poza nią, modlitwę o uzdrowienie praktykowaną w Odnowie, a następnie uzdrowienia wewnętrzne i zewnętrzne - fizyczne (por. Kokott 2011, s. 170-182).

W roku 2000 Kongregacja Nauki Wiary dostrzegła fenomen wspólnot modlitewnych, w których ogłasza się przypadki uzyskanych uzdrowień i wzbudza oczekiwanie następnych takich zdarzeń podczas kolejnych spotkań. Mówi się też w tym kontekście o domniemanym charyzmacie uzdrawiania. Wspomniana kongregacja wydała Instrukcje na temat modlitw w celu osiagnięcia uzdrowienia pochodzacego od Boga (14.09.2000; Kongregacja Nauki Wiary 2001, s. 11-28).

Modlitwa błagalna do Boga o przywrócenie zdrowia jest stałą praktyką chrześcijan znaną we wszystkich epokach Kościoła. Czymś nowym w naszych czasach jest natomiast wzrost popularności działalności kaznodziejów wędrownych, którzy łączą posługę głoszenia słowa Bożego z modlitwą w celu otrzymania uzdrowienia od Boga.

Przepowiadanie terapeutyczne ma podstawy biblijne. Skuteczność zawdzięcza ono nie mądrości czy doskonałości ludzkiej głosiciela, ale działaniu Ducha Świętego, który ,przychodzi z pomocą naszej słabości” (por. Rz 8,26), gdy jest o to pokornie proszony. On wzbudza właściwe usposobienie głosiciela słowa Bożego i odpowiednią modlitwę w sercach wierzących, aby poddali się woli Bożej.

\section{Podstawa biblijna przepowiadania terapeutycznego}

Gdy Izraelici w drodze z Egiptu do Ziemi Obiecanej zostali pokąsani przez węże, szukali ratunku u Mojżesza, by wstawił się za nimi u Boga. „Sporządził więc Mojżesz węża miedzianego i umieścił go na wysokim palu. I rzeczywiście, jeśli kogo wąż ukąsił, a ukąszony spojrzał na węża miedzianego, zostawał przy życiu" (Lb 21,9). Po kilku wiekach autor Księgi Mądrości dokonał reinterpretacji owego uzdrowienia na pustyni, wyjaśniając: „Nie zioła 
ich uzdrowiły ani nie okłady, lecz słowo Twe, Panie, co wszystko uzdrawia" (Mdr 16,12).

Autor Księgi Mądrości miał już świadomość, że słowo Boże ma uzdrawiającą moc. Później zaś słowo Boże stało się ciałem (J 1,14). Wcielone Słowo Boże, Jezus z Nazaretu namaszczony Duchem Świętym (por. Lb 21,6-9; J 3,14-17) nauczał i uzdrawiał. Tłumy ludzi gromadziły się, ,aby Go słuchać i znaleźć uzdrowienie ze swych chorób. Także i ci, których dręczyły duchy nieczyste, doznawali uzdrowienia. A cały tłum starał się Go dotknąć, ponieważ moc wychodziła od Niego i uzdrawiała wszystkich" (Łk 6,18-19).

\subsection{Uzdrowienia dokonane przez Jezusa}

Według Raniera Cantalamessy, niemal jedną trzecią Ewangelii wypełniają relacje o uzdrowieniach dokonanych przez Jezusa (Cantalamessa 2003, s. 335). Z kolei Jan Twardy wyróżnia 18 uzdrowień chorych, z których pięć opisują wszyscy trzej synoptycy, o dwóch mówią dwaj z nich, a 11 pozostałych uzdrowień relacjonuje tylko jeden z ewangelistów. Ogółem osobne opisy uzdrowień chorych znajdują się w 30 tekstach (por. Twardy 2001, s. 156-157). Ponadto w czterech ewangeliach znajduje się 17 tekstów zawierających 12 sumariów, czyli ogólnych wzmianek o licznych uzdrowieniach dokonywanych przez Jezusa (por. Twardy 2001, s. 156, 158).

Jezus, w odróżnieniu od współczesnych sobie cudotwórców znanych z pozabiblijnej literatury greckiej, uzdrawiał, stosując proste gesty i proste formuły słowne. Nigdy nie czynił tego dla osobistego zysku. Natomiast wspomniani cudotwórcy wykonywali skomplikowane rytuały, nierzadko podczas snu chorego. Szukali przy tym zysku i sławy, a nawet odwoływali się do posiadanej mocy w celu zastraszania przeciwników (por. Twardy 2001, s. 163).

Jaki jest sens uzdrowień dokonanych przez Jezusa? Uzdrowienia chorych dokonane przez Niego były ściśle związane z Jego posłannictwem i orędziem (por. Twardy 2001, s. 162-163). Jezus objawił, że Bóg ma władzę nad chorobami i że ludzie chorzy są dla Niego bardzo cenni. „Uzdrowienia są znakami, że tam, gdzie nadeszło królestwo Boże, zmienia się sytuacja ludzi chorych, bo albo odzyskują zdrowie, albo otrzymują moc do znoszenia cierpienia i zostają otoczeni szczególną opieką i troską" (Twardy 2001, s. 161).

W uzdrowieniach Jezusa działa i objawia się sam Bóg, który już w Starym Przymierzu objawił się Izraelowi, oznajmiając: „chcę być twym lekarzem” (Wj 15,26). Wszystko, co Bóg uczynił u początku stworzenia, „było dobre” (Rdz 1,12.18.25.31). Z kolei Marek Ewangelista zrelacjonował, że świadkowie uzdrowienia głuchoniemego w okolicach Dekapolu ,pełni zdumienia mówili: «Dobrze uczynił wszystko. Nawet głuchym słuch przywraca i niemym mowę»” (Mk 7,37). 
Podobnie Dzieje Apostolskie przekazują fragment mowy kerygmatycznej - kazania św. Piotra w Cezarei, w którym stwierdził on: „Znacie sprawę Jezusa z Nazaretu, którego Bóg namaścił Duchem Świętym i mocą. Dlatego że Bóg był z Nim, przeszedł On dobrze czyniąc i uzdrawiając wszystkich, którzy byli pod władzą diabła" (Dz 10,38). W czasie tej sławnej mowy kerygmatycznej św. Piotra Duch Święty zstąpił na wyznawców Boga, którzy zgromadzili się w Jerozolimie.

\subsection{Uzdrowienia dokonywane „w imię Jezusa”}

Jezus udzielił swoim uczniom pełnomocnictwa do uzdrawiania (por. Mk 6,7.13). Nie było ono ograniczone jedynie do czasu Jego ziemskiej działalności, ale obowiązywało także po Jego śmierci i zmartwychwstaniu. Zmartwychwstały Pan obiecał: „Tym zaś, którzy uwierzą, te znaki towarzyszyć będą: [...]. Na chorych ręce kłaść będą i ci odzyskają zdrowie” (Mk 16,17-18). I tak się stało: Jego uczniowie dokonywali uzdrowień „w imię Jezusa Chrystusa" (Dz 3,6; 9,34; Kogler [red.] 2011, s. 775). Liczne cudowne uzdrowienia, które towarzyszyły początkom ewangelizacji, potwierdzały moc Dobrej Nowiny. Pierwsze chrześcijańskie wspólnoty doświadczały, jak moc obiecana przez zmartwychwstałego Jezusa urzeczywistniała się pośród nich. Dzieje Apostolskie opisują uzdrowienie chromego od urodzenia, który przed wejściem do świątyni jerozolimskiej prosił apostołów Piotra i Jana o jałmużnę. Nie mając ani srebra, ani złota, Piotr powiedział: ,[...] W imię Jezusa Chrystusa Nazarejczyka, chodź!» I ująwszy go za prawą rękę, podniósł go. A on natychmiast odzyskał władzę w nogach i stopach. Zerwał się i stanął na nogach, i chodził, i wszedł z nimi do świątyni, chodząc, skacząc i wielbiąc Boga” (Dz 3,6-8).

Cudowne uzdrowienia towarzyszyły nie tylko przepowiadaniu apostołów. Mamy nowotestamentalne świadectwa o uzdrowieniach towarzyszących głoszeniu diakona Filipa w Samarii: ,Tłumy słuchały z uwagą i skupieniem słów Filipa, ponieważ widziały znaki, które czynił. $Z$ wielu bowiem opętanych wychodziły z donośnym krzykiem duchy nieczyste, wielu też sparaliżowanych i chromych zostało uzdrowionych" (Dz 8,5-7; Kongregacja Nauki Wiary 2001, I, 1).

Liczni wierni doświadczali znaków i cudów, a szczególnie cudownych uzdrowień ukazujących moc Bożą towarzyszącą przepowiadaniu Ewangelii. Świadczy o tym wyrzut św. Pawła, który pytał Galatów: „Czy Ten, który udziela wam Ducha i działa cuda wśród was, [czyni to] dlatego, że wypełniacie Prawo za pomocą uczynków, czy też dlatego, że dajecie posłuch wierze?" (Ga 3,5; Kongregacja Nauki Wiary 2001, I, 1). 


\subsection{Uzdrowienia mocą Ducha Świętego}

Uzdrowienia towarzyszące głoszeniu Jezusa Chrystusa i dokonywane „w imię Jezusa Chrystusa” działy się, co podkreśla głównie św. Paweł, mocą Ducha Świętego. Apostoł Narodów, opisując swoje przepowiadanie Ewangelii, któremu towarzyszyły wyraźne znaki i cuda, jakich przez niego dokonał Chrystus, łączy je z mocą Ducha Świętego: „Nie odważę się jednak wspominać niczego poza tym, czego dokonał przeze mnie Chrystus w doprowadzeniu pogan do posłuszeństwa [wierze] słowem, czynem, mocą znaków i cudów, mocą Ducha Świętego" (Rz 15,18-19; por. 1 Tes 1,5; 1 Kor 2,4-5; por. Kongregacja Nauki Wiary 2001, I, 1).

Uzdrowienia łączone były z mocą Ducha Świętego już przez samego Jezusa, który oznajmił w swoim manifeście mesjańskim: „Duch Pański spoczywa na Mnie, ponieważ Mnie namaścił i posłał Mnie, abym ubogim niósł dobrą nowinę, więźniom głosił wolność, a niewidomym przejrzenie" (Łk 4,18). Według Jezusa zatem celem Jego namaszczenia i posłania przez Ducha Świętego jest nie tylko głoszenie Dobrej Nowiny z priorytetową opcją na rzecz ubogich, ale także uzdrawianie. Łukasz Ewangelista zauważył, że po swym chrzcie w Jordanie: „Pełen Ducha Świętego, powrócił Jezus znad Jordanu i przebywał w Duchu [Świętym] na pustyni [...]. Potem powrócił Jezus w mocy Ducha do Galilei” (Łk 4,1.14). Opisując dalsze wystąpienia Jezusa, Łukasz Ewangelista odnotował: „A cały tłum starał się Go dotknąć, ponieważ moc wychodziła od Niego i uzdrawiała wszystkich” (Dz 6,19). W kontekście wcześniejszych stwierdzeń ewangelisty jasne jest, że nie chodziło o jakąś magiczną moc, o ezoteryczne, nieokreślone siły, osobisty urok ani hipnotyczne oddziaływanie, ale o wspomnianą wcześniej „moc Ducha Świętego” (por. Cantalamessa 2003, s. 336).

Święty Ireneusz wskazywał głęboki teologiczny sens zawarty w cudownych uzdrowieniach. Pisząc o uzdrowieniach i wskrzeszeniach dokonywanych przez Pana Jezusa, dowodził, że ludzkie ciało jest w stanie przyjąć działanie Ducha Bożego. W swym dziele Przeciw herezjom (V, 12,6) napisał:

Stwórca wszechświata, Słowo Boże, które na początku uformowało człowieka, znalazłszy swoje stworzenie uszkodzone przez zło, uzdrawiał je we wszelaki sposób, czasami odnawiając wszystkie członki według tego, jak były uformowane na początku, innym razem sprawiając, że człowiek w jednej chwili stawał się cały i zdrowy, przygotowując go w ten sposób do zmartwychwstania (Ireneusz, Przeciw herezjom, V, 12,6; cyt. za: Cantalamessa 2003, s. 335).

Zdaniem więc Ireneusza, fizyczne uzdrowienia dokonane przez Jezusa miały związek ze zbawieniem całego człowieka, jego duszy i ciała. Uzdrowienie ludzkiego ciała jest zapowiedzią i przygotowaniem do jego uwielbienia. 
Interesująca jest także interpretacja przypowieści Jezusa o miłosiernym Samarytaninie podana przez św. Ireneusza. Według niego, Duch Święty jest właścicielem gospody, któremu miłosierny Samarytanin, to jest sam Chrystus, powierza opiekę nad zranioną ludzkością (Ireneusz, Przeciw herezjom, III, 17,3; cyt. za: Cantalamessa 2003, s. 344).

Inny z ojców Kościoła, św. Ignacy z Antiochii mówił, że Jezus to „Lekarz cielesny i zarazem duchowy" (Ignacy z Antiochii, List do Kościoła w Efezie, VII, 2; cyt. za: Cantalamessa 2003, s. 336). Natomiast wiele wieków później św. Bonawentura mówił o Duchu Świętym jako lekarzu: „Duch Święty przychodzi do nas przede wszystkim jako doświadczony lekarz, przynosząc duchowe i cielesne życie. O, jakże mądry to lekarz! Daje On życie tym, którzy umarli duchowo i fizycznie, oraz leczy wszelkie choroby bez pomocy żelaza, bez ognia, bez magicznych słów, jedynie dzięki decyzji swej woli” (Bonawentura, Kazanie na IV niedziele po Wielkanocy, 1 [Quaracchi, IX, s. 309]; cyt. za Cantalamessa 2003, s. 344).

Przez analogię do helioterapii, czyli naświetlania ciała światłem słońca, owo uzdrawiające działanie Ducha Świętego można nazwać pneumaterapią. Chrześcijanin powinien regularnie poddawać się skutecznej terapii Ducha Świętego. „Duch przychodzi z pomocą naszej słabości” (Rz 8,26), gdy tylko jest o to proszony. Terapia dokonywana przez Ducha Świętego polega na przenikaniu Jego niewidzialnego, lecz mocnego światła do ludzkiego umysłu, woli i uczuć (por. Cantalamessa 2003, s. 344). Duch Święty „przenika wszystko, nawet głębokości Boga samego" (1 Kor 2,10). Człowiek zmysłowy zostaje przeobrażony w człowieka duchowego (por. 1 Kor 2,13-15). Święty Paweł pisał do Koryntian, że człowiek zmysłowy nie rozumie tego, co jest z Bożego Ducha; wydaje mu się to głupstwem (por. 1 Kor 2,14). Natomiast człowiek duchowy bardzo sobie ceni wszystko to, co jest z Ducha Bożego.

W pneumaterapii więcej jest do zrobienia niż do zrozumienia. Chodzi w niej o całkowite oddanie się do dyspozycji Boga, o przedstawienie Duchowi Świętemu na modlitwie wszystkich chorób, które osłabiają rozum, wolę i uczucia - wszystkiego, co decyduje o tym, kim jest człowiek.

Warto dodać, że chorwacki profesor Tomislav Ivančić (1938-2017) z Zagrzebia rozwinął hagioterapię jako dyscyplinę naukową mającą na celu udzielenie pomocy cierpiącym. Hagioterapia (gr. Hagios - 'święty', Therapeia 'uzdrowienie') to również metoda duszpasterska bazująca na przekonaniu, że każda choroba fizyczna czy psychiczna obejmuje także wymiar duchowy. Człowiek bowiem jest jednością ciała, duszy i ducha. Metoda ta, według prof. Tomislava Ivančića, jest przydatna szczególnie w leczeniu uzależnień. Modlitwa i słowo Boże pomagają w odkryciu głębokiej wiary, ta zaś niesie ze sobą uzdrawiającą moc (Ivancić [br.], s. 12-16). 


\section{Prymat uzdrowienia wewnętrznego przed uzdrowieniem fizycznym}

Osoby mające opinię ludzi obdarzonych charyzmatem uzdrawiania, takie jak na przykład bp Bronisław Dembowski (1921-), o. Emilien Tardif (1928-1999), s. Briege McKenna OSC (1943-) podkreślali, że w modlitwie w celu osiągnięcia uzdrowienia chodzi przede wszystkim o „uzdrowienie wewnętrzne", które polega na pogodzeniu się z wolą Bożą, co oznacza także zgodę na chorowanie. Człowiek osiąga wówczas wewnętrzny pokój, uspokaja się i cieszy obecnością Boga w swoim życium (por. Dembowski 2001, s. 8-9; McKenna 1993, s. 39).

Siostra Briege McKenna sama doznała uzdrowienia z reumatoidalnego zapalenia stawów podczas gorliwej modlitwy dnia 9 grudnia 1970 roku. Cierpiała wcześniej, przez 10 lat, od 16. roku życia, mając perspektywę wózka inwalidzkiego. Po swoim uzdrowieniu zaczęła pełnić posługę modlitwy o uzdrowienie. Jest znana w Polsce, bo przemawiała podczas Czuwania grup Odnowy w Duchu Świętym na Jasnej Górze w 1995 i 2002 roku, a ponadto głosiła kilka razy rekolekcje dla kapłanów. Będąc kiedyś w Meksyku, przeżyła podczas Mszy Świętej uzdrowienie poparzonego dziecka. Pod koniec Mszy Świętej s. Briege chciała zobaczyć poparzonego chłopca. Gdy podeszła do kobiety, która go przyniosła, pytając, gdzie on jest, ta z uśmiechem odpowiedziała: Jest tam, bawi się. Był całkiem zdrowy. Kobieta wyjaśniła siostrze zakonnej, że przecież w czasie Mszy Świętej przyszedł Jezus. Ta Eucharystia zmieniła całe życie s. Briege. Przekonała się o uzdrawiającym działaniu Ducha Świętego podczas Eucharystii (por. McKenna 1993, s. 39).

W swojej posłudze jednak nie akcentuje ona uzdrowienia fizycznego, ale duchowe. Według niej uzdrowienie polega przede wszystkim na powiedzeniu Bogu ,tak”, jak Maryja, która przyjęła wolę Bożą zwiastowaną jej przez archanioła Gabriela (por. Łk 1,38). Tak więc uzdrowienie w najgłębszym sensie oznacza zgodę na pełnienie woli Bożej, jakakolwiek ona jest. Siostra Briege wyznała: „Zrozumiałam, że moją misją jest pomagać ludziom w mówieniu «tak»" (por. McKenna 1993, s. 39). Podobnie Thomas Forrest i Jose H. Prado Flores twierdzą, że uzdrowienie to proces, który rozpoczyna się wtedy, gdy całkowicie zawierzamy Bogu całe swoje życiu, mówiąc: Zrób ze mną to, co uważasz za słuszne (por. Forrest, Prado Flores 1994, s. 22-23; Kokott 2011, s. 179-180; zob. Kokott 2011, s. 167-182).

Tak więc posługa słowa Bożego powinna być ukierunkowana przede wszystkim na motywowanie słuchaczy do pełnienia woli Bożej, a zatem i na prymat uzdrowienia duchowego. Sam Jezus dał do zrozumienia, że dla Niego najważniejsze jest duchowe uzdrowienie człowieka, bo fizyczne jest tylko na określony czas. Nikt przecież nie żyje na ziemi w nieskończoność. Nawet ci, którzy zostali uzdrowieni przez samego Jezusa, z czasem zapadli na zdrowiu i umarli. 
Wyraźne pierwszeństwo uzdrowienia wewnętrznego przed uzdrowieniem zewnętrznym w posłudze Pana Jezusa zostało uwydatnione w przypadku paralityka, którego przyniesiono do Jezusa. Widząc wiarę jego przyjaciół, powiedział On do chorego: „Synu, odpuszczają ci się twoje grzechy” (Mk 2,5). Czterech kolegów przyniosło paralityka do Jezusa po to, by został uzdrowiony fizycznie, tymczasem Jezus odpuścił mu grzechy, czym wprowadził w zdumienie niektórych świadków tego zdarzenia w Kafarnaum. Uczeni w Piśmie byli zdumieni słowami Jezusa: „Czemu On tak mówi? On bluźni. Któż może odpuszczać grzechy, oprócz jednego Boga?” (Mk 2,7). Znając ich myśli, Jezus wyjaśnił swoje postępowanie i spełnił prośbę o uzdrowienie paralityka:

Cóż jest łatwiej: powiedzieć do paralityka: Odpuszczają ci się twoje grzechy, czy też powiedzieć: Wstań, weź swoje łoże i chodź? Otóż, żebyście wiedzieli, iż Syn Człowieczy ma na ziemi władzę odpuszczania grzechów - rzekł do paralityka: „Mówię ci: Wstań, weź swoje łoże i idź do domu!”. On wstał, wziął zaraz swoje łoże i wyszedł na oczach wszystkich. Zdumieli się wszyscy i wielbili Boga mówiąc: „Jeszcze nigdy nie widzieliśmy czegoś podobnego” (Mk 2,9-11).

Jezus dokonał więc najpierw tego, co najistotniejsze w Jego przepowiadaniu i posłudze: ogłosił pojednanie grzesznika z Bogiem. Następnie zaś podarował mu zdrowie. Jezus przyznał, że łatwo jest powiedzieć: „Odpuszczają ci się twoje grzechy”. Tego nie można zweryfikować w sposób empiryczny. Natomiast fizyczne uzdrowienie paralityka jest czymś ewidentnym, wyjątkowym, a nawet bezprecedensowym. Wielu świadków tego cudownego uzdrowienia mówiło: „Jeszcze nigdy nie widzieliśmy czegoś podobnego” (Mk 2,11). Uzdrowienie zostało celowo połączone przez Jezusa z ogłoszeniem odpuszczenia grzechów. Dla wszystkich stało się jasne: skoro Jezus jednym słowem może sprawić, że paralityk zaczął chodzić, to z taką samą łatwością może oznajmić odpuszczenie grzechów. Ważniejsze było uzdrowienie wewnętrzne aniżeli uzdrowienie fizyczne (por. Dembowski 2001, s. 9-10).

Mamy też w Biblii fragment, który, akcentując skutki zerwania więzi z Bogiem, przedstawia prymat pojednania z Nim i zerwania z grzechem przed dobrym zdrowiem i sprawnością fizyczną. W Kafarnaum po uzdrowieniu epileptyka Jezus uczył, że lepiej jest wejść do życia wiecznego, będąc ułomnym, chromym i jednookim, aniżeli z dwiema rękami, z dwiema nogami i z dwojgiem oczu być wrzuconym do piekła (por. Mk 9,43-48). 


\section{Głoszenie sensu cierpienia jako element przepowiadania terapeu- tycznego - logoterapii}

Ważnym elementem ewangelicznego orędzia jest specyficznie chrześcijańska interpretacja ludzkiego cierpienia. Samo w sobie cierpienie nie ma sensu. Skoro jednak Syn Boży przyjął je na siebie i nie usunął z ludzkiego życia nawet przez swoją odkupieńczą śmierć, to ma ono do odegrania jakąś rolę w ludzkich dziejach (por. Sławiński 2004, s. 217-227). Nigdy do końca nie zrozumiemy sensu cierpienia i zawsze będzie trudno pogodzić jego istnienie z Bożą miłością. Wiemy jednak z objawienia, że ma ono zbawczy sens. Jak zauważył Jan Paweł II, „w Krzyżu Chrystusa nie tylko Odkupienie dokonało się przez cierpienie, ale samo cierpienie ludzkie zostało też odkupione" (SD, nr 19). Cierpienie i choroba nie są już pojmowane jako przekleństwo od Boga. Przeciwnie, mogą być przyjęte jako współudział w zbawczym dziele Chrystusa.

Tak pojmował swoje cierpienia św. Paweł. Wyznał bowiem: „w moim ciele dopełniam braki udręk Chrystusa dla dobra Jego Ciała, którym jest Kościół" (Kol 1,24). W innym zaś miejscu wyraził przekonanie, że jego osobista słabość sprawia, iż tym bardziej uwidacznia się przez niego Boże dzieło. Nie mogąc się doczekać wyzwolenia z ościenia dla ciała (por. 2 Kor 12,7), św. Paweł stwierdził: „Najchętniej więc będę się chlubił z moich słabości, aby zamieszkała we mnie moc Chrystusa. Dlatego mam upodobanie w moich słabościach, w obelgach, w niedostatkach, w prześladowaniach, w uciskach z powodu Chrystusa. Albowiem ilekroć niedomagam, tylekroć jestem mocny" (2 Kor 12,9-10). Podobnie uczy święty Maksym Wyznawca. Według niego „słabość ciała w cierpieniu jest fundamentem dla przepotężnej mocy Ducha" (Maksym Wyznawca, Rozdziały różne, IV, 93 [PG 90, 1345], cyt. za: Cantalamessa 2003, s. 342). Jan Paweł II rozwinął to chrześcijańskie przekonanie, stwierdzając, że ,wielu chorych może żyć «pośród wielkiego ucisku z radością Ducha Świętego» (1 Tes 1,6) i być świadkami Chrystusowego Zmartwychwstania" (por. ChL, nr 53).

Owa radość Ducha Świętego, radość paschalna, która znajduje wyraz W zdolności cierpliwego przyjęcia i znoszenia wszelkiego rodzaju cierpień, jest owocem działania Ducha Świętego. Można powiedzieć, że jest ona owocem pneumaterapii (por. Kongregacja Nauki Wiary 2001, I,1).

Zatem treścią przepowiadania terapeutycznego powinno być wyraźne stwierdzenie, że zwycięstwo Chrystusa nad chorobą i wszelkim ludzkim cierpieniem dokonuje się nie tylko przez ich usuwanie, nie tylko przez cudowne uzdrowienia, ale też wtedy, gdy ludzie dobrowolnie współuczestniczą w męce Chrystusa (por. Kongregacja Nauki Wiary 2001, I,1). Co więcej, Raniero Cantalamessa uważa, że moc Ducha Świętego „,pełniej objawia się w udzielaniu 
nam siły do niesienia z Chrystusem naszych dolegliwości niż w cudownym wybawieniu nas od nich" (Cantalamessa 2003, s. 342) ${ }^{1}$.

\section{Głoszenie w mocy Ducha Świętego z pokorą i poddaniem woli Bożej}

Głoszenie uzdrowienia w imię Jezusa ma korzenie biblijne (por. Mt 4,23) i jest znaną praktyką w historii chrześcijańskiego przepowiadania. Chrześcijanie, zachęceni słowem Bożym, modlą się z wiarą, że Duch Święty może wyleczyć każdą chorobę, kiedy zechce i jak zechce. Jednakże przekonanie, jakoby Bóg na skutek przepowiadania lub modlitwy człowieka musiał dokonać uzdrowienia, nie pochodzi od Ducha Bożego. Nacisk na to, że Bóg ma uzdrowić, kiedy człowiek zechce, świadczy o braku poddania się woli Bożej oraz o braku otwartości na przyjęcie cierpienia, jeśli taka byłaby wola Boża (Mk 8,34; 2 Kor 4,7-11; Kol 1,24; Hbr 5,8; Koordinierungsgruppe der Charismatischen Erneuerung in der Katholischen Kirche 2007, s. 30-31; zob. Buamert [Hrsg.] 1987, s. 46; Pindel 2001, s. 56).

Istnieje niebezpieczeństwo odrodzenia dawnych poglądów sekciarskich takich, jak mesalianizm i pelagianizm. Mesalianie, z syryjskiego „ludzie modlący się", nazywani też po grecku euchitami, tworzyli sektę znaną na Środkowym Wschodzie, w Grecji i Egipcie. Twierdzili, że po grzechu Adama diabeł zamieszkał w każdej duszy i można go wyrzucić tylko wytrwałą modlitwą i życiem ascetycznym. Doświadczając pokus także po chrzcie wodą, twierdzili, że potrzebna jest nieustanna modlitwa, czyli ,chrzest ogniem”. Modlitwa i asceza powinny same z siebie prowadzić do oglądania Trójcy Przenajświętszej. Sekta ta została potępiona przez Sobór Efeski (431). Mesalianizm był na Wschodzie tym, co na Zachodzie określano pelagianizmem. Oba kierunki nauczały, że dzięki wytrwałym wysiłkom człowiek może otrzymać najwyższe duchowe dary (por. O’Collins, Farrugia 2002, s. 94). Współcześni mesalianie uważają, że modlitwą można wyprosić każde uzdrowienie. Skoro Bóg jest wszechmocny, a człowiek na modlitwie odwoła się do wszechmocy Bożej, to może stać się każdy cud.

Podobnie współcześni pelagianie i semipelagianie uważają, że człowiek we współpracy z łaską Bożą może wszystko. Jednak, jak zauważa Franciszek w adhortacji Gaudete et exsultate, wierzący w ten sposób człowiek ,,w istocie przekazuje ideę, że wszystkiego można dokonać za pomocą ludzkiej woli, tak jakby była ona czymś czystym, doskonałym, wszechmocnym, do czego dołącza się łaska. Usiłuje się pomijać, że «nie wszyscy mogą uczynić wszyst-

${ }^{1}$ Szerzej na temat sensu cierpienia, również z perspektywy moralnej, zob. Brusiło 1996, s. 114-141; Sławiński, 2007, s. 213-220; 2001, s. 274-291; Dyk 2018, s. 22-38. 
ko» i że w tym życiu ludzkie słabości nie są całkowicie i raz na zawsze uzdrowione przez łaskę"2.

Błędem, spotykanym w przepowiadaniu niektórych ewangelizatorów, jest kładzenie akcentu przede wszystkim na uzdrowieniu fizycznym, a także głoszenie uzdrowień w powiązaniu z modlitwą o uzdrowienie w takim sensie, że cud musi nastąpić, a jeśli do niego nie dochodzi, to interpretuje się ten brak słabością ludzkiej wiary.

Wraz z Yves'em Congarem (1904-1995) należy zauważyć, że posługa uzdrawiania dobrze znana w Kościele została z czasem jakby zdezawuowana, ale współcześnie odkryto ją na nowo. Zdaniem dominikańskiego teologa: „W naszych czasach krytycznych i tak bogato wyposażonych w środki terapeutyczne dany został mesjański znak bliskiego Królestwa. Kościół odnajduje zapomnianą formę posługi uzdrawiania, która nigdy nie została mu odjęta i która może się przejawiać w wielu innych jeszcze formach" (Congar 1995, s. 219).

Ponieważ Bóg jest wszechmocny i nieograniczony w swoim działaniu, jeśli tylko zechce, może dokonywać uzdrowień w każdej epoce. I często tak się dzieje. Jak zauważył Tarcisio Bertone

W każdej epoce w historii Kościoła istnieli wybrani przez Boga mężczyźni i kobiety, którzy dokonywali uzdrowień, często bardzo licznych, i czynili prawdziwe cuda. W ten sposób na przykład imię Kościoła rozsławili o. Bosco, bł. o. Pio i inni święci. Na pewno i dziś są osoby obdarzone darem uzdrawiania, ponieważ Duch Święty działa w niezmierzonej i całkowitej wolności (Bertone 2001, s. 30).

Jednocześnie T. Bertone nie omieszkał zauważyć, że należy wyraźnie rozróżnić prawdziwy dar uzdrawiania, który powinien być zawsze zbadany przez Kościół, od mitologizacji i idealizacji pewnych osób, które rzekomo dokonały wielu tysięcy uzdrowień. „Takie zjawisko jest nie do pomyślenia w Kościele, ponieważ Duch Święty musi mieć możliwość działać tam, gdzie chce. Ważne jest więc, aby nie idealizować, nie faworyzować jedynie niektórych spotkań modlitewnych" (Bertone 2001, s. 31) ${ }^{3}$.

Jeśli tylko Bóg chce, jako wszechmocny, może dokonywać wszelkiego rodzaju uzdrowień: fizycznych, duchowych i dotyczących relacji społecznych. W Księdze Jeremiasza pada pytanie, dotyczące kondycji Izraela: „Czy nie ma

${ }^{2}$ Franciszek, O powołaniu o świętości w świecie wspótczesnym «Gaudete et exsultate» (19 marca 2018), 49; http://w2.vatican.va/content/francesco/pl/apost_exhortations/documents/papafrancesco_esortazione-ap_20180319_gaudete-et-exsultate.html [dostęp: 10.02.2019].

${ }^{3}$ Kongregacja Nauki Wiary, List «Iuvenescit Ecclesia» do Biskupów Kościoła katolickiego na temat relacji między darami hierarchicznymi a charyzmatycznymi dla życia i misji Kościoła (15.05.2016), 8; 17. 
już balsamu w Gileadzie, czy nie ma tam lekarza? Dlaczego więc nie zabliźnia się rana Córy mojego ludu?" (Jr 8,22). Uaktualnionej odpowiedzi na to pytanie proroka udziela współczesna pieśń African-American spirituals: „W Gilead jest balsam, który zabliźnia rany / W Gilead jest balsam, który uzdrawia grzeszne dusze" "4. Gilead był znany z lekarzy, a także z oleju wytwarzanego $\mathrm{z}$ lokalnego drzewa gumowego. Wierzono, że balsam ten ma leczniczą siłę. Bóg jednak przez proroka Jeremiasza oświadcza, że nie balsam z Gileadu, ale tylko Bóg może usunąć każde cierpienie fizyczne i niesprawiedliwość społeczną, bo tylko On sprawuje całkowitą kontrolę nad światem. W interpretacji pieśni spirituals balsamem z Gileadu jest Jezus, natomiast według Raniera Cantalamessy jest nim Duch Święty: „Balsam z Gileadu był zaledwie odległą figurą Ducha Świętego" (Cantalamessa 2003, s. 345). Pierwsza zwrotka wspomnianej pieśni wskazuje na odradzające działanie Ducha Świętego: „Czasem czuję zniechęcenie i myślę, że ma praca jest daremna / Wtedy Duch Święty odradza mą duszę na nowo" (por. Cantalamessa 2003, s. 346). Tak, Duch Święty jest odnowicielem i pocieszycielem. On jest obecny i działa w Kościele katolickim i poza nim. Kościół katolicki w wieloraki sposób okazuje troskę o tych, „którzy się źle mają”. Spieszy im z pomocą między innymi przez sakrament chorych, a także przez głoszenie uzdrawiającej mocy Jezusa. Może przy tym z pokorą prosić o jej manifestację na chwałę Boga i ku wiecznemu pożytkowi ludzi.

\section{Podsumowanie}

Podjęte zagadnienie jest bardzo ważne zarówno w refleksji teologicznej, jak i praktyce duszpasterskiej. Domaga się ono dalszego pogłębienia. W podsumowaniu przeprowadzonych analiz można stwierdzić, że głoszenie uzdrowienia w imię Jezusa i z mocą Ducha Świętego jest możliwe i właściwe, o ile zachowana będzie pamięć o tym, że:

- Bóg jest wszechmocny, obecny i działający, zwłaszcza podczas liturgii.

- Uzdrowienie może się dokonać również poza liturgią i poza Kościołem katolickim.

- Bóg nie związał daru uzdrawiania z hierarchią kościelną, ale zadaniem hierarchii jest czuwanie, by nie dochodziło do nadużyć i wypaczeń w życiu chrześcijańskiej wspólnoty.

${ }^{4}$ Psalter Hymnal, Gray 1987; https://hymnary.org/text/sometimes_i_feel_discouraged_spiritual [dostęp: 0.02.2019]. 
- Kościół ma szczególny sakrament - sakrament chorych, przez który przychodzi z pomocą ludziom dotkniętym chorobą, cierpieniem i doświadczeniem umierania.

- Jeśli cudowne uzdrowienia naprawdę mają miejsce, są świadectwem mocy Dobrej Nowiny. Ani cuda dokonane przez Jezusa na palestyńskiej ziemi, ani te zdziałane mocą Ducha Świętego podczas przepowiadania przez członków Kościoła nie powinny być interpretowane jedynie z perspektywy apologetycznej, czyli wyłącznie jako potwierdzenie prawdziwości głoszonej nauki. Należy raczej podkreślać fakt, że Jezus przyszedł ,zbawić to, co zginęło” (Łk 19,10), a więc, że uzdrowienia są wyrazem troski Boga o ludzi w doczesnym życiu. Siłą chrześcijaństwa, czynnikiem, który przyczynił się do jego rozpowszechnienia, była troska o całego człowieka, o zbawienie jego duszy, ale też i o zdrowie ciała.

- Zmartwychwstały Chrystus uczy patrzeć na życie w perspektywie eschatologicznej, a więc z przekonaniem, że życie ludzkie zmienia się, ale się nie kończy: doczesna kondycja ludzka nie jest ostateczna, choć życie wieczne zaczyna się dla każdego już w życiu na ziemi.

- Cierpienie, choć samo w sobie jest złem, zostało przez Chrystusa odkupione.

- Wobec fenomenu głoszenia uzdrowień należy pamiętać o zachęcie św. Pawła: „Ducha nie gaście, proroctwa nie lekceważcie! Wszystko badajcie, a co szlachetne - zachowujcie! Unikajcie wszystkiego, co ma choćby pozór zła" (1 Tes 5,19-22), a więc należy popierać to, co dobre, a korygować to, co niewłaściwe.

- Osoby głoszące słowo Boże w połączeniu z modlitwą w celu osiągnięcia uzdrowienia powinny odznaczać się wysokim życiem moralnym, szlachetnością obyczajów, wiernością nauczaniu Kościoła oraz mieć misję kanoniczną. W Kościele bowiem ważne jest posłanie do przepowiadania: udzielane przez sakrament święceń oraz misję kanoniczną.

PREACHING THE HEALING IN THE NAME OF JESUS AND IN THE POWER OF THE HOLY SPIRIT: THERAPEUTIC PREACHING

\section{SUMMARY}

In many countries, also in Poland, there are preachers of the word of God, identifying themselves mainly with the movement of the Renewal in the Holy Spirit, which stresses the healing power of Jesus. Such preaching has biblical foundations in the healings of Jesus of Nazareth and in healings in the power of the Holy Spirit "in the name of Jesus." The contemporary therapeutic preaching, the content of which is the 
healing action of Jesus, should take into account the priority of inner healing before physical healing, and include proclaiming the sense of suffering, which was not removed by Jesus, who himself took it up to the death on the cross. In addition, the authentic preaching of healing in the name of Jesus always takes place in the power of the Holy Spirit, with humility and submission to the will of God. It is not the preacher who decides whether, when and how healing is done, but only God, who is omnipotent and sovereign in his actions.

Keywords: preaching; healing; Holy Spirit

Słowa kluczowe: przepowiadanie; uzdrowienia; Duch Święty

\section{BIBLIOGRAFIA}

Bertone T. (2001), Prawda o instrukcji..., w: Instrukcja na temat modlitw w celu osiagnięcia uzdrowienia pochodzacego od Boga z komentarzem teologicznym, Kraków, s. 29-31.

Brusiło J. (1996), Życie bez bólu? Chrześcijański sens cierpienia a przeciwbólowe działania medycyny, Kraków, s. 114-141.

Cantalamessa R. (2003), Pieśń Ducha Świętego. Rozważania na temat „Veni Creator”, thum. M. Przeczewski, Warszawa.

Congar Y. (1995), Wierzę w Ducha Świętego, t. 2, thum. L. Rutowska, Warszawa.

Dyk S. (2018), Problematyka cierpienia w przepowiadaniu homilijnym, „Kieleckie Studia Teologiczne" 17, s. 22-38.

Dembowski B. (2001), Wprowadzenie, w: Instrukcja na temat modlitw w celu osiagnięcia uzdrowienia pochodzacego od Boga z komentarzem teologicznym, Kraków, s. 7-10.

Forrest T., Prado Flores J.H. (1994), Jezus Chrystus, uzdrowiciel mojej osoby, thum. K. Skorulski, Łódź.

Hajduk R. (1996), Leczyć rany serc złamanych. Przyczynek do kaznodziejstwa terapeutycznego, Kraków.

Ivancić T. ([br.]), Grundlagen der Hagiotherapie, Zagreb br. [pierwsze wydanie: Graz 1998].

Jan Paweł II, List apostolski Salvifici doloris (11.02.1984) https://opoka.org.pl/biblioteka/W/WP/ jan_pawel_ii/listy/salvifici.html [dostęp: 10.02.2019].

Jesus ist der Herr. Kirchliche Texte zur Katholischen Charismatischen Erneuerung (1987), Hrsg. N. Buamert, Münsterschwarzach.

Kogler F. red. (2011), Nowy leksykon biblijny, thum. Ł. Siemieniec, Kielce.

Kokott N. (2011), Rola Ruchu Odnowy w Duchu Świętym w dynamizowaniu misji Kościoła, Kraków.

Kongregacja Nauki Wiary (2001), Instrukcja na temat modlitw w celu osiagnięcia uzdrowienia pochodzacego od Boga (14.09.2000), w: Instrukcja na temat modlitw w celu osiagnięcia uzdrowienia pochodzacego od Boga z komentarzem teologicznym, Kraków, s. 11-28.

Koordinierungsgruppe der Charismatischen Erneuerung in der Katholischen Kirche (2007), Der Geist macht lebendig (Joh 6, 63). Theologische und pastorale Grundlagen der Charismatischen Erneuerung in der Katholischen Kirche Deutschlands, Maihingen.

McKenna B. (1993), Portret własny, w: Radość uzdrawiania braci, pr. zb., tłum. T. Jania, J. Klimek, J. Kokowska, Kraków, s. 33-42.

O’Collins G., Farrugia E.G. (2002), Leksykon teologiczny, tłum. J. Ożóg, B. Żak, Kraków. 
Pindel R. (2001), Charyzmaty uzdrowień - od Biblii do dokumentu Kongregacji Nauki Wiary, w: Instrukcja na temat modlitw w celu osiagnięcia uzdrowienia pochodzacego od Boga z komentarzem teologicznym, Kraków, s. 45-61.

Sławiński H. (2007), Ambiwalentne postawy człowieka wobec cierpienia, „Studia Włocławskie” 10, s. $213-220$.

Sławiński H. (2001), Bóg i człowiek wobec cierpienia, „Ateneum Kapłańskie” 555-556, z. 2-3, s. $274-291$.

Sławiński H. (2004), Logoterapia V.E. Frankla i przepowiadanie homilijne, „Studia Włocławskie” 7, s. 217-227.

Suráb M. (2008), Teraputický rozmer homílie, Bratislava.

Twardy J. (2001), Głoszenie cudów Jezusa dzisiaj, Kielce, s. 210-260.

\section{Publikacje w wersji elektronicznej}

Franciszek, Adhortacja o powołaniu do świętości w świecie współczesnym "Gaudete et exsultate» (19 marca 2018), http://w2.vatican.va/content/francesco/pl/apost_exhortations/documents/pa pa-francesco_esortazione-ap_20180319_gaudete-et-exsultate.html [dostęp: 10.02.2019].

Kongregacja Nauki Wiary, List "Iuvenescit Ecclesia» do Biskupów Kościoła katolickiego na temat relacji między darami hierarchicznymi a charyzmatycznymi dla życia i misji Kościoła (15.05.2016), https://episkopat.pl/relacja-miedzy-darami-hierarchicznymi-acharyzmatycznymi-list-kongregacji-nauki-wiary/, [dostęp: 10.02.2019].

Psalter Hymnal, Gray 1987; https://hymnary.org/text/sometimes_i_feel_discouraged_spiritual [dostęp: 10.02.2019].

Henryk Sławiński - ks. profesor dr hab., homileta i pedagog. Wykładowca na Uniwersytecie Papieskim Jana Pawła II w Krakowie, w Wyższym Seminarium Duchownym w Tarnowie i w Wyższym Seminarium Duchownym Księży Misjonarzy św. Rodziny. Redaktor naczelny kwartalnika „Polonia Sacra”. Przewodniczący Stowarzyszenia Homiletów Polskich, członek Międzynarodowego Towarzystwa „Fides et Ratio” i Polskiego Towarzystwa Teologicznego. 